\title{
A Conceptual Approach to Unveil Traditional Homegardens as Fields of Social Practice
}

\author{
Diana Gabriela Lope-Alzina ${ }^{1,2^{*}}$
}

\begin{abstract}
Disciplines and approaches concerned with people-environment relations have contributed to legitimate traditional ecological knowledge, nowadays endorsed in the international scientificpolicy agenda as an important driver for management and conservation of biological resources. However, there is still a need to further understand how people internalize worldviews, knowledge, and practices regarding environmental management. In this sense, traditional homegardens are a suitable scenery to unravel such processes. Grounded on Bourdieu's 'theory of practice', this paper unveils homegardens as fields of social practice. The homegarden field is embedded within the household field, further influenced by the community field. The three of them make up the 'array of fields' where homegardening develops by means of social interactions, informing and informed by the habitus (schemes of perception, appreciation, and action, produced by particular social environments that shape agent's own sense of the world and his/her place in it). Both, inputs (e.g. land, plants, labor, and knowledge) and outputs (e.g. increased knowledge, homegarden produce, homegarden functions and derived benefits) are here approached as homegarden's capitals. According to the theory of practice, such capitals are unequally distributed across agents, and it is such inequality that impulses them to generate, maintain, increase and/or transform homegarden capitals.
\end{abstract}

Keywords: Ethnoecology; Biocultural Diversity; Gender Studies in Agriculture; Forms of Capital; Social-Ecological Systems; Bourdieu's Theory of Practice

\footnotetext{
1 Tecnológico Nacional de México, Instituto Tecnológico de Tlalpan, Av. Cerrada Sta. Cruz. no. 4, San Miguel Topilejo, Ciudad de México, CP 14500.

${ }^{2}$ Wageningen University and Research Center, Gender Studies in Agriculture. Hollandseweg 16706 KN, Wageningen, The Netherlands.

* $\quad$ E-mail address: DGLA (dlope@yahoo.com)

\section{INTRODUCTION}

Traditional knowledge has been recognized as a driver for biodiversity management and conservation in the international arena, as in the case of the

Intergovernmental Science-Policy Platform on Biodiversity and Ecosystem Services (IPBES). As stated by authors concerned with this topic: "indigenous and local knowledge systems represent alternative ways of learning from and with the
} 
environment, through close and continuous observation framed by distinct worldviews" (Tengö et al. 2017). Nevertheless, several disciplines and approaches focused in people-environment relations antecede such legitimization. That is the case of socialecological systems (SES) and ethnoecology.

Born from ecology, SES acknowledges the reciprocal relationships between the social and the ecological systems (Berkes et al. 2000a). This is found, for example, in the conceptualization of 'indigenous ecological knowledge' which has been defined as "a cumulative body of knowledge, practice, and belief, evolving by adaptive processes and handed down over generations by cultural transmission, about the relationships between living beings and their environment" (Berkes et al. 2000b).

Derived from cognitive anthropology, ethnoecology is concerned with the way in which traditional societies organize and classify their knowledge about the surrounding environment (Brosius et al. 1986). Ethnoecology has been extensively approached to study reciprocal relationships between nature and culture in traditional societies (e.g. Alexiades 2009; Hunn 2008; Johnson and Hunn 2010; Toledo 1991; Sillitoe 2001). For example, the approach proposed by Toledo (1991), emphasizes in that worldviews (kosmos), knowledge (korpus), and practice (praxis) are intertwined and undividable. Such a compound informs the way in which local people perceive the surrounding environment, making up the saberes tradicionales (traditional knowledges) which are stored in the mnemonics of people who have been in close interaction with the environment through generations. Such knowledge is also referred as biocultural memory, which denotes the coevolution of biological and cultural diversities as well as the adaptive feature of individuals and societies to cope and manipulate their environments (Toledo and Barrera-Bassols 2008).

The focus of this paper is in homegardens, the land use system where social relations are most readily visible as based on knowledge, practice, use, management, and cosmologies (Howard 2006). Indeed, homegardens are generally managed through 'unpaid' household labor and are due to knowledge that has taken a life time to accrue (ibid.). Also, labor, knowledge, and rights to homegarden resources are often differentiated within the household and within the social group according to attributes such as age, sex, and social position (ibid.). In fact, homegardens are said to reflect internal aspects of both the domestic and the socio-cultural group where they are embedded (Finnerman and Sackett 2004; Lope-Alzina 2012).

Homegarden research has its origins in agroforestry in the 1970's (Fernandes and Nair 1986). Eventually, this land use system has risen interest across disciplines such as ethnobotany, agroecology, geography, and anthropology. Similarly, while homegarden research initially focused on the cultivated areas by the habitational unit (e.g. Barrera 1980), in the last fifteen years, the interest over this land use system has extended to urban and peri-urban contexts as in the case of urban gardens, community gardens, and allotments (see Calvet-Mir et al. 2012; Ellen and Platten 2011; Ellen and Komaromi 2013). The growing interest in different types of gardens seems to be related to a growing concern about food security, food sovereignty, organic food, and the therapeutic value of gardening and food production for own-consumption (e.g. González-Ball et al. 2017; Hake 2017; McClintock and Simpson 2017; McFarland 2017; Pineda Ofreneo and Hega 2016).

Due to the social nature of homegardens, 
through this paper; I present a conceptual proposal to unearth the social practice that underlies this land use system; the purpose is to make a theoretical contribution to the study of homegardens. As previously mentioned, while disciplines or approaches concerned with the co-evolution of nature and society have contributed to legitimate traditional ecological knowledge, there is still a need to build a deeper understanding about how agents and social groups internalize worldviews, knowledge, and practice (e.g. kosmos-korpus-praxis). In fact, approaches such as ethnoecology and social-ecological systems still show gaps about how such processes inform the perceptions and ways to act in relation to the surrounding nature and the ways in which it is appropriated in both a utilitarian (e.g. provision of food and other goods) and nonutilitarian sense (e.g. aesthetic and ritualistic values). The justification of this proposal relies in such needs.

\section{Why Bourdieu?}

The proposed approach put forth here departs from Pierre Bourdieu's 'theory of practice' (Bourdieu 1977, 1990). Bourdieu's form of exposition is known to be highly complex, ambiguous, and difficult (Fourny 2000). However, by departing from three general concepts -fields, habitus, and capitals- and the interplay among them, the complexity of social relations in a given context can be better understood. These three concepts and their interrelations have been used to understand social phenomena across a wide range of disciplines, such as education (Dumais 2004), gender studies (Krais and William 2000; McCall 1992; McNay 1999), and linguistics (Hanks 2005). In people-environment relationships, a few case studies refer to habitus as means to explain adherence to traditional ecological knowledge. This is the case of Greenberg (2003) and Waldstein and Adams (2006) who explain that, as part of habitus, rural migrants often bring planting material of species they consume as food, from their original places to their new places. Yet, the potential that Bourdieu's approach has to unveil the interrelations between social relations and biological resources or ecosystems is not thoroughly approached through such research.

Bourdieu's social practice is said to be rooted in classical sociology with authors such as Marx, Weber, Durkheim, and Veblen (Di Maggio 1979; Fourny 2000; Sallaz and Zavisca 2007); an overall intellectual project concerned with 'the synthesis of the objectivist and subjectivist epistemologies' (Sulkunen 1982). Largely influenced by Immanuel Kant, Bourdieu criticized both 'empty theoricism and blind empiricism' in the social sciences (Bourdieu 1988), advocating for the need for an 'emic' approach that relies on ethnographical methods but is not necessarily divorced from, and rather complements, quantitative data (Bourdieu 1990). With this approach, he provided an analytic framework that himself named a 'reflexive cognitive anthropology' (Bourdieu and Wacquant 1992). In this regard, the complementarity between 1) theory and practice, and 2) the quantitative and the qualitative, are currently acknowledged as the most comprehensive approach in the study of people-environment relationships (e.g. Albuquerque et al. 2014).

\section{The 'field" in the context of homegardens}

The field in Bourdieu's sense has been defined as a 'the social world in which actors are embedded and toward which they orient their actions' (Sallaz and Zavisca 2007); it is the social arena where predispositions 
acquired through socialization and experience provide the agent with a 'sense' about how to 'play' in the field itself (Jenkins 1992). The position hold by the agent in the field, is influenced by factors outside it, which are eventually 'translated to the internal logic of the field' (Martin 2003: citing Swartz 1997). In Bourdieu's 'theory of practice', a field interconnects with other fields, making up the 'array of fields' through which the agent experiences the immediate social world.

In the conceptualization here proposed, the homegarden field is embedded within the household field, in turn embedded within a broader field, the social group or the community. This complex make up 'the array' of fields through which the agent internalizes homegardening as one of his/her most proximal social experiences. The three fields and their interrelations are next addressed.

\section{The homegarden field}

The agent at the homegarden field is both a household member and a gardener who through socialization and experience has learned to reproduce the homegarden system and all of its elements and functions (Howard 2006). This entails maintaining both inputs (e.g. knowledge, labor, land, and species) and outputs (e.g. produced goods and functions such as improved nutrition, additional household income, increased status, and improved bargaining power over wage income) (see Mitchell and Hanstad 2004).

In this sense, the homegarden field has its own capitals 'at play' and its own rules to follow. For example, in the Yucatan (Mexico), the homegarden is considered as a 'female bounded space' even when women rarely own the land. Nevertheless, through their knowledge and labor, women are able to yield de facto rights over the garden and its produce; this allows them to generate status and prestige, and to bargain and negotiate. In this way, the homegarden becomes a field of social practice for women where they do not compete with men (see Lope-Alzina 2004, 2014).

\section{The household field}

The household or domestic group refers to the social arena where the individual derives his or her first modes of thinking, expressions, dispositions, and meanings (Hanks 2005; Jenkins 1992; Reay 2004). One of the most accepted definitions, developed within cultural anthropology, states that 'the household is the basic residential unit where economic production, consumption, inheritance, child rearing, and shelter are organized and carried out' (Haviland et al. 2005). In the same line, the household is perceived as a unit of 'domestic organization' where members are not necessarily kin related and the referent is the 'geographical propinquity or common residence' (Yanagisako 1979).

The above conceptualizations however do not provide insights into the household's inner dynamics. As it is well known, within the household there exists differentiations according to age, sex, and hierarchies as directly related to the division of tasks and distribution of both obligations and benefits (Kabeer 1991).

The division of labor, knowledge, benefits and responsibilities within the household can be understood through the lens of homegardens. For this reason, the homegarden and the household are here posited as interrelated fields of social practice. Indeed, across the literature, it has been found that the household is the main source of knowledge and labor for the homegarden (Hoogerbrooge and Fresco 
1993; Howard 2006; Mitchell and Hanstad 2004), with household members having differentiated rights, responsibilities, and duties at different moments (Howard and Nabanoga 2007). For example, in the Yucatan, men are in charge of the garden settlement while women eventually become main labor providers, knowledge holders, and decision-makers about what to grow, where in the garden, and how to use it. All that as part of a subtle negotiation process between men and women, which fits expected social roles (Lope-Alzina 2004).

\section{The community field (public sphere)}

Household members are social agents who 'interact dynamically with the larger society', therefore the household cannot be separated from the community or the public sphere (Hendon 1996). The same idea is supported by Furåker and Peterson (2006) who state that 'without neighborhood contacts and stable relationships between family members in and outside the individual households, the community will not function.' Similarly, Yanagisako (1979) acknowledges that changes in social relations in the public sphere are reflected in the internal organization of the domestic group.

In this context, exchanges of planting material and other goods that originate and/or enter homegardens are a clear example of the interrelations between both the homegarden and the community fields. Authors such as Ban and Coomes (2004); Calvet-Mir et al. (2012), Díaz-Reviriego et al. (2016,) Ellen and Komaromi (2013), Ellen and Platten (2011), and Lope-Alzina (2014) have shown the reciprocal relationship between gardens (homegardens and community gardens) and social relations; such exchanges reinforce social networks while contributing to build and maintain gardens. Moreover, such exchanges are means to reinforce local social dynamics.

\section{'Habitus' in the context of homegardens}

As proposed by Bourdieu, the habitus is a notion about the reciprocal relationship between social and mental structures: 'social structures inculcate mental structures [and] these mental structures in turn may reproduce or change social structures' (Sallaz and Zavisca 2007). The habitus is defined as 'a system of durable and transposable dispositions (schemes of perception, appreciation, and action) produced by particular social environments, which functions as the principle of the generation and structuring of practices and representations' (Bourdieu 1988). This highly elaborated definition implies four things. First, as a disposition, habitus is 'an embodied sense of the world and one's place within it' - a 'tacit feel for the game' (Sallaz and Zavisca 2007, citing Bourdieu 1984), which is produced as a matter of routine rather than consciously learned (Jenkins 1992). Second, habitus is durable, meaning that it is the result of a process that is 'internalized in individuals through early socialization in the family or primary group' (Sallaz and Zavisca 2007). Third, habitus is transposable, meaning that 'people carry their dispositions with them as they enter new settings' (ibid.). Fourth, habitus is not immutable: it is constantly shaped by the agent's experiences and socialization processes (Sulkunen 1982).

Habitus is therefore quite a complex concept (Bourdieu and Wacquant 1992): while grounded in cognitive structures, it is by no means mechanistic; while built on past experiences (internalized belief, trial-error, 
learning) it is, however, guided by the future (what is to be achieved); while the agent is unconsciously predisposed to carry out determined actions and have determined belief and interests, habitus still gives room for conscious action and agency; it is a kind of learned empirical knowledge, but it is one that cannot be 'explicitly articulated' (McNay 1999). Habitus is manifest, for example, in dietary patterns, language expressions, accents, dress styles, aesthetic codes, housing lay outs (Sulkunen 1982), and, it is here posited, in homegardens.

The traditional homegardener has assimilated or 'embodied' the establishment and maintenance of this agroecosystem as part of his/her social world and the place that he/ or he has in it. Homegardening knowledge and abilities are acquired through experience as a matter of routine, largely at the unconscious level. Homegarden habitus is 'durable', meaning that it is often learned through early socialization processes and stays with the homegardener throughout life. Last but not least, since the agent 'carries' his or her homegardening habitus as he or she enters new settings, homegardening habitus is 'transposable' and always subject to change, yet it does not disappear as the agent first learned it, but rather, it is constantly shaped as the he or she engages in new experiences (e.g. new forms of cultivation, commodity production, migration).

The above hypotheses are supported by homegarden research across the world. For example, in a literature review covering 39 case studies with both homegardens and swidden gardens across Latin America, Howard (2006) provides evidence that gardening is learned through socialization processes that develop early in life, enhanced and increased through life-time; therefore habitus -a form of unconscious disposition is part of life, and is congruent with social norms and expected behavior. Even if the gardener acquires new knowledge or enters new contexts, the essence of what is learn early in life about gardening, remains within him or her for life.

The above arguments may contribute to understand why homegardens are due to the gardeners (Kimber 2004) and why homegardens have been able to cope and evolve with external factors, such as the intensification of agriculture (Hoogerbrugge and Fresco, 1993). Also, they may explain the diversification into other types of 'new' gardens, such as urban, community, and school gardens.

\section{The "capital" and its forms in the context of homegardens}

Capital, a concept rooted in Classical Economics, refers to 'a stock that possesses the capacity of giving rise to flows of goods and/or services' (Ekins et al. 2003). In Bourdieu's theory of practice, capitals are defined as 'the goods or resources that are at stake in fields' (Jenkins 1992; Reay 2004) which can be found 'in three fundamental guises' -economic, cultural, and social-. These forms of capital are contextual and convertible into one another depending on the 'field' where the capital is 'at stake', posited to be unequally distributed across individuals in a given field (Bourdieu 1990, 2003, 2004).

The three main forms of capital proposed by Bourdieu are described in this section together with two other forms -natural capital and symbolic capital-, both considered of key importance to understand homegardens as fields of social practice.

\section{Economic capital}

Bourdieu's notion of economic capital involves both material and non-material 
investments which, through time, may return an economic benefit that is not necessarily financial (Sallaz and Zavisca 2007). In this way, Bourdieu's conceptualization of economic capital rejects the reductionist view of economic theory about mercantile exchange and profit maximization of economic theory (Ibid.), which neglects other forms of exchange than monetary.

In homegardens, land, labor, and use and exchange values of homegarden goods can be regarded as economic capital. An example of this is the cash generated from plants and animals grown at homegardens which are sold at small scale, usually at local or regional markets (e.g. Abebe 2013; Barbosa de Lima 2014; Lope-Alzina 2014; Major et al. 2005; Mitchell and Hanstad 2004).

\section{Cultural capital}

Cultural capital encompasses knowledge and skills (Reay 2004). The concept was introduced by Bourdieu into the social sciences as a hypothesis about the uneven distribution of knowledge and skills. That explains, for example, why some individuals succeed in a given 'field' while others don't (ibid.). Indeed, if one possesses cultural capital, one is said to be competitive in a given 'socially valued area of practice' (Sallaz and Zavisca 2007).

In this paper, I hypothesize that the cultural capital of homegardens consists on the one hand, of knowledge and skills, and on the other hand, of the cultural functions that the homegarden itself yields. In the first case, knowledge and skills can be highly specialized and may cover from plant propagation and cultivation management to storage, processing, and knowledge about market value (Howard 2006). For example, in the Yucatan, a squash landrace locally known as 'tzol' is cultivated preferably in homegardens, where women are main knowledge holders about this species' management -cultivation, plant care, processing, storage-, and are also who sell this squash at local markets (Lope-Alzina 2007). In the second case, the social functions of homegardens contribute to reproduce local social dynamics. As shown by Christie (2005), kitchens and homegardens match for knowledge transfer about food processing and preparation; this as part of the cultural tradition, for example, when women gather together to cook for local festivities and rituals.

\section{Social capital}

Social capital is defined as 'durable networks of relations through which individuals can mobilize power and resources' (Bourdieu and Wacquant 1992). It consists of the aggregate of relationships of mutual acquaintance and appreciation among people in a durable network where group relations represent the basis through which people can yield benefits from other people through reciprocity (Bourdieu 1986). Of all of the forms of capital, social capital is the least possible to achieve individually since it largely depends on the socialization processes and established relations with other agents (Bourdieu 1986, 2004).

Regarding homegardens, social capital relates to exchanges (e.g. of seed, planting material, goods, and knowledge) which reinforce social networks. Such exchanges are often non-monetary and may yield access to resources such as land, goods, labor, knowledge, and social status (Ban and Coomes 2004; Calvet-Mir et al. 2012; Coomes et al. 2015; Díaz-Reviriego et al. 2016; Ellen and Komaromi 2013; Ellen and Platten 2011; Jaimovich 2015; Lope-Alzina 2014). 


\section{Natural capital}

This form of capital was not explicit in Bourdieu's conceptualization of the social world, yet, as a concept accepted in the international agenda, it has been here included.

Natural capital is also called environmental or ecological capital; it is defined as a stock that generates "a flow of 'services', which serve as inputs into the productive processes" (Ekins et al. 2003). Due to their biological richness and multiple uses values, homegardens are rich in natural capital, which consists of the biotic and abiotic elements therein contained (see Brookfield and Stocking 1999). In fact, a key characteristics of the homegarden agroecosystem, is that it may concentrate a high number of plant species in relatively small areas (Anderson 1996; Barrera 1980; Lope-Alzina 2007; Mitchell and Hanstad 2004).

\section{Symbolic capital}

Symbolic capital is understood as a form of recognition by others expressed as prestige, esteem, honor, authority, and charisma (Reay 2004). This form of capital may act as the underlying 'force' in the conversion of the forms of capital. For example, cultural capital (e.g. homegardening knowledge), when acknowledged by others, may yield both economic returns (cash from petty sales) and social capital (relations, networks, connections).

Symbolic capital in homegardens is here perceived as the recognition, acknowledgement, or appreciation as a good gardener, which is earned by virtue of personal skills and abilities while it also fits with the expected social roles. Therefore, symbolic capital in homegardens consists of social status ${ }^{1}$ and prestige. For example, in the Amazonia, Piaroa women attain prestige by means of manioc cultivation and processing, a food staple in the region which is grown in swidden gardens ${ }^{2}$ (Heckler 2004).

Related to the above, social position -defined by attributes such as age, sex, roles, and hierarchy within a group- also influences the status that someone gets from homegardening. In the Yucatan, for example, elderly women are very active in exchange networks while they are also appreciated as knowledge beholders. Such a capital hold by these women, influences the high hierarchies they have in social networks as related to their social status and prestige (Lope-Alzina 2014).

\section{The essential capitals to establish a homegarden}

Certain capitals are first needed to establish a homegarden: land (preferably of certain quality) and planting materials, which demand both labor and knowledge. These four capitals knowledge, labor, land, and plant genetic resources- are herewith described.

Homegarden knowledge. This type of knowledge is understood as the acquired body of information that is necessary to carry out a minimum of practices for garden

\footnotetext{
1 Status can be either achieved or ascribed. The former is earned by virtue and reflects personal skills, abilities, and efforts; the latter is either given from birth or later assumed in life (Keesing and Strathern 2001).

2 Swidden gardens are considered to have the same importance in socio-cultural terms in the Amerindian Amazonas than homegardens for Mesoamerica and other regions of South America (Howard 2006).
} 
establishment and maintenance. As suggested before, homegarden knowledge can be approached as cultural capital since it is embodied by the agent and validated through social interactions. This knowledge is highly specialized as related, for example, to the large number of species maintained and to the several forms of knowledge needed (e.g. from agroecology to supplydemand and related price fluctuations) (Lope-Alzina 2004).

Homegarden labor. Labor can be approached as economic capital in that it represents an investment of time, skills, and physical work; eventually yielding means of subsistence. The main source of homegarden labor is the household, presumably due to the proximity between the household and the homegarden, and to the fact that labor requirements in homegardens are generally low and spread throughout the year (Hoogerbrooge and Fresco 1993).

Homegarden land. This input can be considered as both economic and natural capital. In the first case, because of the subsistence means as a land use system where a diversity of species are grown and used by the household in several forms and end-destinations (e.g. own-consumption, markets). In fact, land is an economic asset since property rights exist over it (in fact, land may be sold, purchased, inherited, etc.). In the second case, as an abiotic component of homegardens, land is a means for all types of life reproduction, which among other functions, yield ecosystem services such as carbon sequestration (Kumar 2006).

Plant genetic resources. Homegardens are not conceivable without plants; other components such as domestic animals, and wild animals that find a refugee, may become part of garden once it has been established (González-Jácome 1985). Plants or more specifically, plant genetic resources or PGR (plants, seed, propagation material, fruits, flowers, etc.) can be approached as multi-fold capital. They are natural capital since they provide own means of biological reproduction, generating an incommensurable flow of services that promote the continuation of reproductive processes (Ekins et al. 2003). PGR can also be approached as economic capital since it provides means of subsistence, either directly as in the case of own-consumption, or for the cash potentially generated. Last but not least, PGR are cultural capital: technical environmental knowledge is implicit in pre-harvest (e.g., plant adaptation, nutrient requirement, and growing habits) and postharvest management (storage and preservation, processing and preparation according to specific uses and requirements as in the case of culinary, medicinal, or ritualistic applications). Moreover, 'individual plants may take on social meaning' (Howard 2006), as when plants become a remembrance of specific events or of relations with other people.

Plants as cultural capital show an interesting trend with plant uses and thus with homegarden's functions. As proposed by Bourdieu (1986), the forms of capital can be transformed into one another. In the case of homegarden plants, it is the use and functions given to a plant or a species that defines the specific form or forms of capital it may have. For example, if the plant is used for ritualistic purposes as in the case of Tagetes erecta L., zempazuchitl, the iconic flower of Day of the Death celebrations in México, the capital is cultural; or, if the plant is used for medicinal purposes, the capital may be both economic and cultural; if the plant is given as gift, it may become a means to enhance social capital. 


\section{The 'bundle' of social relations around homegarden capitals}

Both homegarden inputs (as those described in the previous section) and outputs (e.g. increased knowledge, species, and populations; cash generation, and social status attainment) are 'feed' by social relations, which circulate through the 'array' of fields - the homegarden, the household, and the community-. Borrowing the term from Ribot and Peluso (2003), such relations are here referred as a 'bundle' of social relations because they are all interrelated; herewith presented as part of the local social norms:

Social differentiations. Agents have differentiated roles in daily life according to the position they have in both the domestic and public spheres (Bourdieu 1990; 2004). Such differentiation is due to factors such as age, sex, ethnic group, migratory status, and religious and political affiliations, and may be reflected in the agent's status (e.g. economic and/or social, including honor and esteem by others).

Knowledge relations. Knowledge refers to the information embodied in the agent that he or she needs in order to perform practices. In the case of agroecosystems such as homegardens, knowledge can be described as 'traditional' in that 'it takes a life time to accrue' (Howard 2006): also, because it is transmitted mostly -but not necessarily only- via practical and oral means (Ellen and Harris 2000). Garden knowledge is hypothesized to be unequally distributed across household and community members, depending on the contact the agent has with the stimuli (Boster 1985).

Labor relations. Refer to the distribution of physical work among agents, implying an investment of time, skills, and physical activities. In subsistence economies, the labor required to build and maintain local agroecosystems, develops within the household, where different members have different yet complementary labor inputs (Lope-Alzina 2007).

Property Relations. This dimension refers to interactions among individuals or agents with regard to tenure of a given asset; relationships where rights and access differ across individuals and social contexts. Rights can be formal (entitlement recognized by the law) or customary (privileges often gained through labor, knowledge, and specific uses and applications given to the resource). Access means that the individual has 'room' to make use of the resource and derived goods, thus receiving a benefit without necessarily being the 'entitled' owner (Howard and Nabanoga 2007). Both, access and rights imply "who does (and who does not) get to use what, in what ways, and when (that is, in what circumstances)" (Ribot and Peluso 2003, citing Neale 1998).

Exchange Relations- Exchanges are part of the subsistence economy and more often than not, flow through specific networks defined by social affinities and kinship ties (e.g. Díaz-Reviriego et al. 2016). For instance, exchanges may be a means to gain material goods (e.g. food) and nonmaterial assets, such as prestige, honor, and esteem (Lope-Alzina 2014). Exchanges can be material (items such as plants, animals, and processed homegarden goods) or nonmaterial (as in the case of knowledge).

Herewith some examples of the interrelations between homegarden's capitals and the social relations above described:

- Management and use of PGR are strongly linked to social differentiations as related to permissions and prohibitions (Howard 2006). That is, a given person can make a given use of a given part of a 
given plant that is grown in a given place or land use system in a given season (Howard and Nabanoga 2007)- Also, men and women may have different permissions and restrictions in regard to specific crops, species and cultivars (Howard 2006) and such gender associations may imply exclusions (Boster 1985).

- Seeds and planting material are especially important in exchange relations. For instance, goods generated in homegardens are often exchanged between kin, reinforcing social relations (Calvet-Mir et al. 2012; Coomes et al. 2015; Díaz-Reviriego et al. 2016; Ellen and Komaromi 2013; Ellen and Platten 2011; Jaimovich 2015).

- Homegarden knowledge may influence property relations. This is the case of women who are not be entitled to own homegarden land. However, they may be able to yield customary rights through the knowledge and labor they invest in homegardens (Howard and Nabanoga 2006).

- Rights and access over homegarden assets can be generated by means of labor. However, divisions of labor are rooted in worldviews of what is considered to be appropriate behavior, usually related to the agents' social position (sex, age, kinship relations, and social status). Male and female, young and old, siblings and parents, may have different yet complementary labor inputs (Howard 2006).

- Land as an asset implies social relations. This can be perceived by looking at the horizontal layout of the homegarden (with zones defined by use: ornamentals, medicinals, spices, fruit trees, timber, cash-crops, livestock, etc.). Each zone is usually cared and managed by household member(s) with assigned tasks according to attributes such as age, sex, and hierarchies within the household (Mendez et al. 2001).

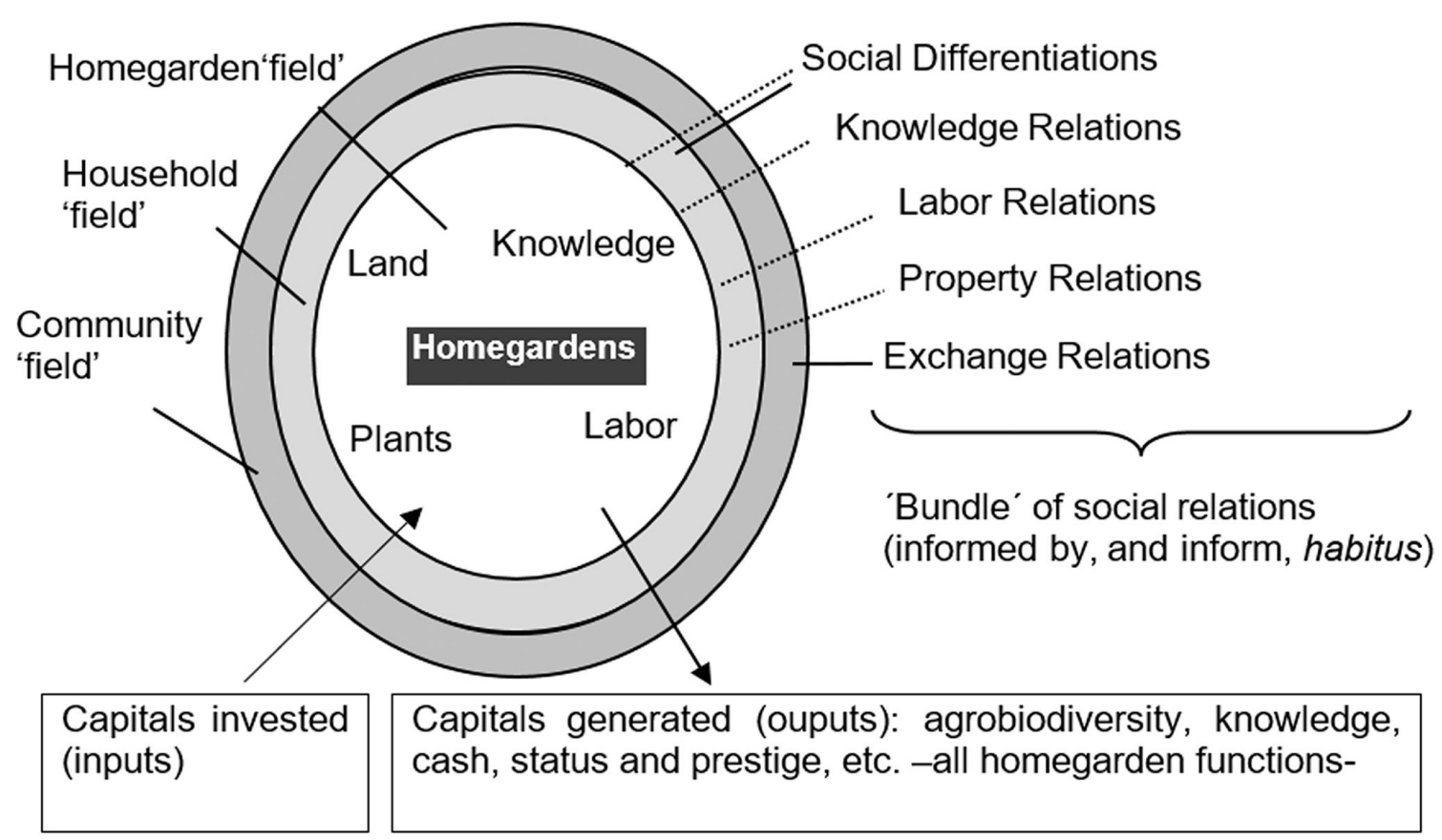

Figure 1. Homegardens as fields of social practice 


\section{'A feel for the game': understanding homegardens as fields of social practice}

Grounded on Bourdieu's theory of practice, through this paper, homegardens have been unveiled as 'fields' of social practice with its own capitals 'at play' and its own inner dynamics. As illustrated in Figure 1 , the homegarden field is fully embedded within the household or domestic 'field' and it is further influenced by the community 'field' to which the household belongs. Therefore, the homegarden, the household, and the community or larger social group make up the 'array of fields', which is mobilized through the 'bundle' of social relations, which inform and are informed by the agents' habitus -schemes of perception, appreciation, and action, produced by particular social environments that shape agent's own sense of the world and his/her place in it- (Bourdieu and Wacquant 1992).

\section{CONCLUSIONS}

In spite of the increased body of knowledge in people-environment approaches such as ethnoecology and social-ecological systems, which emphasize in the interrelations and coevolution of people with their environments, there is still a need to further understand how people "embodies" such cognitive processes. Similarly, while traditional knowledge has been recognized as a driver for biodiversity management and conservation in the international arena, there are still scientific gaps to legitimate such knowledge: the social sciences and approaches as the one developed through this paper represent a potential contribution to fill such gaps.

Taking Bourdieu's theory of practice as a conceptual framework to address the social world of homegardens, through this paper, I have highlighted that -as stated by Bourdieuperceptions about use, management, and world-views are internalized by the agent through the interactions within the social group since early in life, and carried out with him or her as he or she enters new settings. Such habitus is here posited to play a key role in the maintenance of homegardens, a traditional agroecosystem.

The household is the arena through which relations with other households are established as a means to assure and increase the household's own capitals. To unfold this idea, it is necessary to remind ourselves that, in Classical Sociological Theory, capitals are entrenched in social relations (see Swedberg 2006); they are produced and held by agents who engage in knowledge relations, labor relations, property relations, exchange relations, and social differentiations, and are (re)distributed and exchanged among the same and other agents.

Embedded in both the household and the social group fields, homegardens are both units of production and fields of social practice where the overall goal is to achieve, maintain, increase, and/or transform certain capitals that are 'at stake'. At this field, the agent holds certain position, which is dictated by the habitus, embodied by him or her since early in life and carried out within him or her as he or she enters new settings. In this regard, traditional homegardening remains with the agent through life, continuously adapted to new circumstances and characterized by certain features that have been passed from generation to generation as part of the social practice that characterizes a given group. 


\section{ACKNOWLEDGEMENTS}

The author is thankful to the Mexican Council for Science and Technology (CONACYT) for the fellowship no. 196675 granted to pursue doctoral studies at Wageningen University; to the School of Anthropology and Conservation at the University of Kent at Canterbury for the academic exchange between 2009 and 2011 when the literature review for this paper was first set. Special thanks to Prof. Patricia Howard who made this paper possible by means of her advice and feedback.

\section{REFERENCES}

Abebe T (2013). Determinants of Crop Diversity and Composition in Enset-Coffee Agroforestry Homegardens of Southern Ethiopia. Journal of Agriculture and Rural Development in the Tropics and Subtropics, 114(1):29-38.

Albuquerque UP, da Cunha LVFC, Lucena RFP, Alves RRN (2014). Methods and Techniques in Ethnobiology and Ethnoecology. Springer, New York. $480 \mathrm{Pp}$.

Alexiades MN (2009). Mobility and Migration in Indigenous Amazonia: Contemporary Ethnoecological Perspectives. Berghahn Books, New York. 304 Pp.

Anderson EN (1996). Gardens of Chunhuhub. In: Hostettler U. (ed.) Los Mayas de Quintana Roo: Investigaciones Antropológicas Recientes. Institut für Ethnologie der Universität Bern, Switzerland, pp. 63-77.

Ban N, Coomes OT (2004). Home Gardens in Amazonian Peru: Diversity and Exchange of Planting Material. Geographical Review 94:348367.

Barbosa de Lima A (2014). Flavors of the City: Access to Regional Fruit and Fruit Consumption in the State of Acre, Brazil. Boletim do Museu Paraense Emílio Goeldi. Ciências Humanas, 9:79-92.

Barrera A (1980). Sobre la Unidad de Habitación Tradicional Campesina y el Manejo de Recursos Bióticos en el Área Maya Yucatanense. Biótica 5(3):11-129.
Berkes F, Folke C, Colding J (2000a). Linking Social and Ecological Systems: Management Practices and Social Mechanisms for Building Resilience. Cambridge University Press; New York. 459 Pp.

Berkes F, Colding J, Folke C. (2000b). Rediscovery of Traditional Ecological Knowledge as Adaptive Management. Ecological Applications, 10(5), 1251-1262.

Boster JS (1985). Selection for Perceptual Distinctiveness: Evidence from Aguaruna Cultivars of Manihot esculenta. Economic Botany 39:310-325.

Bourdieu P (1977) Outline of a Theory of Practice. Cambridge University Press, Cambridge. 258 Pp.

Bourdieu P (1986). The Forms of Capital. In: Richardson JG (ed.) Handbook of Theory and Research for the Sociology of Education. Greenwood Press, New York, pp. 241-258.

Bourdieu P (1988). Vive la Crise!: For Heterodoxy in Social Science. Theory and Society 17:773-787.

Bourdieu P (1990). The Logic of Practice. Stanford University Press, Redwood. $333 \mathrm{Pp}$.

Bourdieu P (2003). Participant Objectivation. Journal of the Royal Anthropological Institute 9:281-294.

Bourdieu P (2004). From the King's House to the Reason of State: A Model of the Genesis of the Bureaucratic Field. Constellations 11:1636.

Bourdieu P, Wacquant, LJD (1992) An Invitation to Reflexive Sociology. Chicago University Press, Chicago. $332 \mathrm{Pp}$.

Brookfield H, Stocking M (1999) Agrodiversity: Definition, Description and Design. Global Environmental Change 9:77-80.

Brosius P, Lovelace GW, Marten GG (1986). Ethnoecology: An Approach to Understanding Traditional Agricultural Knowledge. In Marten GG. (Ed.), Traditional Agriculture in Southeast Asia: A Human Ecology Perspective (pp. 187198). Westview Press, Boulder, pp. 187-198.

Calvet-Mir L, Calvet-Mir M, Molina JL, ReyesGarcía, V (2012) Seed Exchange as an Agrobiodiversity Conservation Mechanism. A Case Study in Vall Fosca, Catalan Pyrenees, Iberian Peninsula. Ecology and Society 17(1):29. 
Christie ME (2006). Kitchenspace: Gendered Territory in Central Mexico. Gender, Place and Culture, 13(6):653-661.

Coomes OT, McGuire SJ, Garine E, Caillon S., McKey D, Demeulenaere E, Jarvis D, Aistara G, Barnaud A, Clouvel P, Emperaire L, Louafi S, Martin P, Massol F, Pautasso M, Violon C, Wencélius J (2015) Farmer Seed Networks Make a Limited Contribution to Agriculture? Four Common Misconceptions. Food Policy 56:41-50.

Díaz-Reviriego I, González-Segura L, Fernández-Llamazares A, Howard PL, Molina JL, Reyes-García V (2016) Social Organization Influences the Exchange and Species Richness of Medicinal Plants in Amazonian Homegardens. Ecology and Society 21(1).

Di Maggio P (1979) Review: On Pierre Bourdieu. The American Journal of Sociology 84:1460-1474.

Dumais SA (2004) Cultural Capital, Gender, and School Success: The Role of Habitus. Sociology of Education 75:44.

Durkheim E (1893) The Division of Labor in Society [Online]. Assumption College. http://www.sociologycentral.com/theory/readings/t heoryreadingsindex.html [Accessed 2203 2011].

Ekins P, Simon S, Deutsch L, Folke C, DeGroot R (2003) A Framework for the Practical Application of the Concepts of Critical Natural Capital and Strong Sustainability. Ecological Economics 44:165-185.

Ellen RF, Harris H (2000) Introduction. In: Ellen RF, Parkes P, Bicker, A. (eds.), Indigenous Environmental Knowledge and its Transformations: Critical Anthropological Perspectives. Harwood, Amsterdam, pp 1-34.

Ellen RF, Komáromi R (2013) Social Exchange and Vegetative Propagation: An Untold Story of British Potted Plants. Anthropology Today 29(1):3-7.

Ellen RF, Platten S (2011) The Social Life of Seeds: The Role of Networks of Relationships in the Dispersal and Cultural Selection of Plant Germplasm. Journal of the Royal Anthropological Institute 17(3):563-584.

Fernandes ECM, Nair PKR (1986). An Evaluation of the Structure and Function of Tropical Homegardens. Agricultural Systems, 21(4), 279-310.
Finerman R, Sackett R (2003). Using Home Gardens to Decipher Health and Healing in the Andes. Medical Anthropology Quarterly, 17(4), 459-482.

Fourny JF (2000) Introduction. Special issue: Pierre Bourdieu. SubStance 29:3-6.

Furåker B, Peterson A (2006) Special Issue on Social Capital: Editorial Comments. Acta Sociologica 49:123-125.

González-Ball R, Bermúdez-Rojas T, RomeroVargas M (2017). Floristic Composition and Richness of Urban Domestic Gardens in Three Urban Socioeconomic Stratifications in the City Heredia, Costa Rica. Urban Ecosystems, 20(1):51-63.

González-Jácome A (1985) Homegardens in Central Mexico. In: Farrington IS (ed.) Prehistoric Intensive Agriculture in the Tropics. Archaeopress, Oxford, pp. 521-537.

Greenberg LSZ (2003) Women in the Garden and Kitchen: The Role of Cuisine in the Conservation of Traditional House Lot Crops among Yucatec Maya Immigrants. In: Howard PL (ed.) Women and Plants: Gender Relations in Biodiversity Management and Conservation. Zed Books, London and New York, pp. 51-65.

Hake BJ (2017). Gardens as Learning Spaces: Intergenerational Learning in Urban Food Gardens. Journal of Intergenerational Relationships, 15(1):26-38.

Hanks WF (2005) Pierre Bourdieu and the Practices of Language. Annual Review of Anthropology 34:67-83.

Haviland WA, Prins HE, Walrath D, McBride B (2005). Cultural Anthropology: The Human Challenge. Thomson Wadsworth, Belmont, CA. $448 \mathrm{Pp}$.

Heckler SL (2004) Tedium and Creativity: The Valorization of Manioc Cultivation and Piaroa Women. The Journal of the Royal Anthropological Institute 10(2):241-259.

Hendon JA (1996) Archaeological approaches to the organization of domestic labor: household Practice and Domestic Relations. Annual Review of Anthropology 25:45-61.

Hoogerbrugge I, Fresco OL (1993) Homegarden Systems: Agricultural Characteristics and Challenges, Sustainable Agriculture and Rural Livelihoods. Gatekeeper Series No. 39. United Nations Environment Programme \& International Institute for Environment and Development. London. $23 \mathrm{Pp}$. 
Howard PL (2006) Gender and Social Dynamics in Swidden and Homegardens in Latin America. In: Kumar BM, Nair PKR (eds.) Tropical Homegardens: A Time-Tested Example of Sustainable Agroforestry. Springerlink Netherlands, Dordrecht. pp.159-182.

Howard PL, Nabanoga G (2007) Are there Customary Rights to Plants? An Inquiry among the Baganda (Uganda), with Special Attention to Gender. World Development 35:1542-1563.

Hunn ES (2008) A Zapotec Natural History: Trees, Herbs, and Flowers, Birds, Beasts, and Bugs in the Life of San Juan Gbëë. University of Arizona Press, Tucson. 261 Pp.

Jaimovich D (2015) Missing Links, Missing Markets: Evidence of the Transformation Process in the Economic Networks of Gambian villages. World Development 66:645664.

Jenkins R (1992) Pierre Bourdieu (Key Sociologists). Routledge -Taylor and Francis Group, London and New York.. 206 Pp.

Johnson LM, Hunn ES (2010). Landscape Ethnoecology: Concepts of Biotic and Physical Space. New York: Berghahn Books, New York. 332 Pp.

Kabeer N (1991) Gender, Production and WellBeing: Rethinking the Household Economy. Discussion Paper 288. Brighton, Institute of Development Studies. $35 \mathrm{Pp}$.

Keesing RM, Strathern AJ (2001) Cultural Anthropology: A Contemporary Perspective. Harcourt Brace College Publishers, Fort Worth, Texas and London,. $565 \mathrm{Pp}$.

Kimber CT (2004) Gardens and Dwelling: People in Vernacular Gardens. Geographical Review 94:263-283.

Krais B, William JM (2000) The Gender Relationship in Bourdieu's Sociology. SubStance 29:53-67.

Kumar BM (2006). Carbon Sequestration Potential of Tropical Homegardens. In: Kumar BM, Nair PKR (2006) Tropical Homegardens: A Time-Tested Example of Sustainable Agroforestry. Springerlink Netherlands, Dordrecht. pp. 185-204.
Lope-Alzina DG (2004). Gender Relations as a Basis for Varietal Selection in Production Spaces in Yucatan, Mexico. Thesis, Master of Science. Wageningen University Research, Department of Social Sciences. Wageningen, the Netherlands. $115 \mathrm{Pp}$.

Lope-Alzina DG (2007) Gendered Production Spaces and Crop Varietal Selection: Case Study in Yucatan, Mexico. Singapore Journal of Tropical Geography 28:21-38.

Lope-Alzina DG (2012) Avances y Vacíos en la Investigación en Huertos Familiares de la Península de Yucatán. En Mariaca R (Coord.). El Huerto Familiar del Sureste de México. El Colegio de la Frontera Sur y Secretaría de Recursos Naturales y Protección Ambiental del Estado de Tabasco, p. 98-110.

Lope-Alzina DG (2014). Una Red Comunal de Acceso a Alimentos: El Huerto Familiar como Principal Proveedor de Productos para Intercambio en una Comunidad Maya Yucateca. GAIA Scientia, Volume Especial Populações Tradicionais, 8(2):199-215.

Major J, Clement CR, DiTommaso A (2005). Influence of Market Orientation on Food Plant Diversity of Farms Located on Amazonian Dark Earth in the region of Manaus, Amazonas, Brazil. Economic Botany, 59(1):7786.

Martin JL (2003) What Is Field Theory? The American Journal of Sociology 109:1-49.

McCall L (1992) Does Gender Fit? Bourdieu, Feminism, and Conceptions of Social Order. Theory and Society 21:837-867.

McClintock N, Simpson M (2017). Stacking Functions: Identifying Motivational Frames Guiding Urban Agriculture Organizations and Businesses in the United States and Canada. Agriculture and Human Values, 34(1):1-21.

McFarland AL (2017). The Relationship between the Use of Green Spaces and Public Gardens in the Work Place on Mental Wellbeing, Quality of Life, and Job Satisfaction for Employees and Volunteers. HortTechnology, 27:187-198

McNay L (1999) Gender, Habitus and the Field: Pierre Bourdieu and the Limits of Reflexivity. Theory, Culture \& Society 16:95-117. 
Méndez V, Lok R, Somarriba E (2001) Interdisciplinary Analysis of Homegardens in Nicaragua: Micro-Zonation, Plant Use and Socioeconomic Importance. Agroforestry Systems 51:85-96.

Mitchell R, Hanstad T. (2004). Small Homegarden Plots and Sustainable Livelihoods for the Poor. FAO Livelihood Support Programme (LSP), Working Paper no. 11. Food and Agriculture Organization, Access to Natural Resources Sub-Programme. Rural Development Institute, USA, Seattle. $44 \mathrm{Pp}$.

Pineda Ofreneo R, Hega MD (2016). Women's Solidarity Economy Initiatives to Strengthen Food Security in Response to Disasters: Insights from Two Philippine Case Studies. Disaster Prevention and Management: An International Journal, 25(2):168-182.

Reay D (2004) Gendering Bourdieu's Concepts of Capitals? Emotional Capital, Women and Social Class. The Sociological Review 52:57-74.

Ribot JC, Peluso NL (2003) A Theory of Access*. Rural Sociology 68:153-181.

Sallaz JJ, Zavisca J (2007) Bourdieu in American Sociology. 1980-2004. Annual Review of Sociology 33:21-41.

Sillitoe P (2001) Pig Men and Women, Big Men and Women: Gender and Production in the New Guinea Highlands. Ethnology 40(3):171192.

Sulkunen P (1982) Society Made Visible: On the Cultural Sociology of Pierre Bourdieu. Acta Sociologica 25:103-115.
Swedberg R (2006) Capitalism. In: Turner BS (ed.) The Cambridge Dictionary of Sociology. Cambridge University Press, Cambridge. Pp. 4955.

Tengö M, Hill R, Malmer P, Raymond CM, Spierenburg M, Danielsen F, Elmqvist T, Folke C. (2017). Weaving Knowledge Systems in IPBES, CBD and Beyond-Lessons Learned for Sustainability. Current Opinion in Environmental Sustainability, 26:17-25.

Toledo VM (1991) EI Juego de la Supervivencia, un Manual para la Investigación Etnoecológica en Latinoamérica. CLADES, Berkeley, California, $75 \mathrm{pp}$.

Toledo VM, Barrera-Bassols N (2008) La Memoria Biocultural: la Importancia Ecológica de las Sabidurías Tradicionales. Icaria Editorial, Barcelona. 230 pp.

Waldstein A, Adams C (2006) The Interface Between Medical Anthropology and Medical Ethnobiology. Journal of the Royal Anthropological Institute 12:S95-S118.

Yanagisako SJ (1979) Family and Household: The Analysis of Domestic Groups. Annual Review of Anthropology 8:161-205.
Received: 18 July 2017

Accepted: 03 September 2017

Published: 10 November 2017 